\title{
Capital and capabilities in education: Re-examining Australia's 2015 PISA performance and context assessment framework
}

\begin{abstract}
This paper offers a conceptual framework that combines Sen's concept of capability and Bourdieu's forms of capital to understand the generative mechanisms of educational advantage or disadvantage. Through an examination of Australia's 2015 Program for International Student Assessment (PISA) performance and contexts assessment framework, the paper illustrates some ways that the Sen-Bourdieu framework can be applied. It suggests educational disadvantages are attributable to economic capital and other forms of capital within broader structural, representational and relational contexts of schooling practices. The policy implications for improving equity in education are to recognise forms of capital that enable or limit students' educational capabilities, identify contexts and schooling practices in which limitations occur, and improve opportunities as well as processes in schools to reduce barriers to capabilities in ways that secure students' differences and uniqueness.
\end{abstract}

\section{Key words}

Capital, capabilities, habitus, educational disadvantage, PISA, social justice

\section{Introduction}

Educational disadvantage is a significant factor in students' educational outcomes. The 2015 Program for International Student Assessment (PISA) report indicated that educational performances across all participating countries are associated with the background characteristics of students and mediating factors in schools (Organisation for Economic Cooperation and Development, 2016a). In this regard, educational disadvantage is seen as a lack of access to quality education and a lack of positive environment for learning experiences at school and at home. PISA 2015 concluded that "socio-economic status continues to have an impact on students' opportunities to benefit from education and develop skills" (OECD, 2016a: 39).

At the policy level, PISA 2015 has pointed policy makers to the need of attending to students and schools with lower socioeconomic background to improve their educational performance. In Australia, the policy debate tends to revolve around issues of improving access to schools and school participation for students from disadvantaged backgrounds. For example, the Gonski Review Reports (I and II) recommended a national needs-based and sector-blind school funding model to reduce the country's identified performance gap between high and low 
socio-economic status students and schools and declining PISA performance in the last decade (Commonwealth of Australia, 2017; Thomson et al., 2017). These recommendations underpin the acknowledgement that schools are not equitable in their distribution of material benefits, and that students are not equitably positioned to take up schooling practices because of different socioeconomic backgrounds. Thus, the aim of these policies is to redistribute resources by allocating extra funding to students on the basis of economic need to support increased school participation and achievement.

It is important to recognise that educational investments - public and private financing of schools - and their consequences do not occur in a vacuum. This is because educational disadvantages, that are symptomatic of socioeconomic disparities, are shaped by broader cultural, political and educational contexts in which students, families, and schools operate (Keddie 2012). This paper discusses these contexts in three aspects: 1) structural aspects refer to the overlapping structures of schools and school systems and the material consequences of interactive disadvantages that take place at the student, teachers and school level; 2) relational aspects refer to cultural construction of student identities, their relations with schools, teachers and peers, and consequences of participation in classroom that further marginalise their socioeconomic disadvantage background; 3) representational aspects refer to students' voice and educational values that may be erased if access to existing school systems and practices entrench their marginalised experiences. Understanding these contexts give us insights into how educational disadvantages which appear in socioeconomic differences actually come about. Is it the individual students' cultural differences and uniqueness that put them in an educational disadvantaged position? Or is it that they have abort their cultures to conform with structures and norms of an educational system (which do not align with their personal values) that marginalise their participation, motivation and outcomes. The paper underscores the idea of social justice as plurality, that is human beings are different and unique (Arendt 1958) and policies to improve social justice in education should be about protecting, securing and creating a space to disclose these differences and uniqueness.

This paper offers a conceptual framework that draws on Amartya Sen's $(1985,1999)$ capability approach to view education and Pierre Bourdieu's (2006) forms of capitals to understand the contexts (structures, relations and representation) in which education outcomes may or may not be achieved. The framework aims to understand aspects in these contexts that act as conditions for students to perceive and take up educational resources in ways that they value - educational advantage; or that they are conditioning students in certain ways that could limit their opportunity to take up resources and participate in schools in ways that they value - educational disadvantage. The framework posits that there is an intimate link between people's ownership of capitals and their capabilities, that is, people's stock of capital can enable material resources to convert to capabilities. The relationship between capital and 
capabilities is proposed as follows. Bourdieu's forms of capital (cultural, social, symbolic) are ultimately convertible to economic capital which can provide a means to achieve positive educational outcomes (Bourdieu 2006). Economic capital can be the means to achieve education outcomes, but it is the value (or worth) of the person's owned capitals (cultural, social, symbolic) in certain contexts (fields) which they are being deployed that provide the person with the opportunity to achieve the educational outcomes that they value - educational capability (Sen 1985). Providing the means to students by way of additional economic resources, although important, may not always reduce educational inequality. Rather, we have to understand the contexts in which certain forms of capital can act, or not act, to convert a person's resources to capabilities in order to understand contributing factors to educational inequality. As Sen (1985) put it, knowing the "inequality of what" is important to improve equality.

This paper offers an analytical approach to assess the contexts in which Bourdieu's forms of capital enable or limit students' participation and achievement in education as viewed through Sen's concept of capability. The paper will illuminate the proposed Sen-Bourdieu framework through a discussion of the OECD PISA's contexts assessment framework and some of its indicators in PISA 2015 for Australia (OECD, 2016b). The discussion highlights the importance of creating opportunities as well as processes in schools for students from disadvantaged backgrounds that account for their different stocks of capitals and situations. In offering policy implications, the paper views the role of education as promoting democratic citizenship in pluralistic societies (Nussbaum, 2006), rather than acquisition of knowledge and skills for economic productivity and competitiveness of individuals and societies as underscored by the OECD and current Australian educational policies frameworks.

The paper will first discuss Sen's capability approach to provide a lens to understanding capabilities in education. Bourdieu's forms of capital will then be introduced as conceptual tools to examine the derivation of opportunity and process aspects of Sen's capabilities. The next section will illustrate some of the ways in which the framework can be applied to further understand the findings of Australia's 2015 PISA results, particularly the OECD's contexts assessment framework that underpin the survey questionnaire to teachers, principals, students and parents to supplement the PISA results. The final section will offer some policy implications for social justice policies in education.

\section{Sen's capability approach}

Sen's capability approach is a general normative framework. Sen (1999) argues that the design of social policies and institutions, and the evaluation of wellbeing, inequality, poverty and justice should focus primarily on peoples' capabilities to function. Functionings are various 
combinations of "beings and doings" of a person, such as working, reading, writing, being physiologically and psychologically healthy, being educated, and so on (Robeynes 2003). Functionings can relate to aspects of cultural recognition, for example, feeling respected in a school community; or representational aspects such as having a voice in the school community; or structural aspects such as being able to enrol in the local school; or material aspects for example having access to books or scientific equipment. For Sen, it is important to focus on people's real opportunities to achieve functionings, which he defines as a person's capabilities. In other words, capability is a potential functioning, and all the person's capabilities together form a capability set, which represents his/her real or substantive freedom to be and do the things that he/she value being and doing (Robeyns, 2011). There are enormous variations in what people value and the ways in which they can convert their resources into doings and beings, which depend on the freedom that they have to derive what ends, and what power they have to convert resources into achievements.

The capability approach is appealing for designing and evaluating education practices and outcomes, particularly policies for social justice in education, in two ways. First, the capability approach considers it is more important what people value in life rather than the resources they have access to or the level of satisfaction that they are able to attain. This is because resources alone may present opportunity structures that can include or exclude different people, and the satisfaction that people can attain is dependent on their social, cultural, economic and historical contexts - what Sen refers to as adaptive preferences (Sen, 1985a).

Second, Sen's perspective of freedom allows educationists and policy makers to recognise and examine the diversity of people's lives. At the heart of the capability approach, education plays a role in individuals' wellbeing, their opportunities to acquire skills and knowledge, contribute to political and community life and being open to different cultures (Walker and Unterhalter, 2007). Being educated is a basic capability to aspire to because it is significantly important in itself, and also instrumentally useful in improving other capabilities and increasing the opportunity of one's life (Sen 1997).

Sen's concept of capability allows for thinking about education in terms of the substance of a person, as beings, and the application of a person, as doings, through its emphasis on agency. Sen's vision of agency is an individual who has own goals, although such goals may also include others' goals; he/she can make own choice and actions; and is not a mere recipient of resources as inputs (Pham, 2016). Freedom and agency involve both an opportunity aspect - why they do or choose certain practices, and a process aspect - how they go about doing and choosing what they do (Sen, 1999). In the context of improving educational equity, Sen's view of agency puts to the forefront the potential of students from disadvantaged backgrounds in bringing about self-determination and resources that may (or may not) lead to empowering choices and actions. Furthermore, it allows for real opportunities to improve conditions for people to take 
up education to be identified, which are not limited to the circumstantial factors that people have to contend with. This is because the capability approach recognises that education does not take place in a vacuum. Social structures such as school sectors, students selection, schooling practices and patterns of racial, economic and gender inequality are conditioning factors of student participation that contribute to uneven educational outcomes (Robeyns, 2008). Even for persons with good educational resources, a variety of other factors in family and community life influence their prospects. Thus, to understand how students from diverse backgrounds participate in schools and whether such participation can bring about real opportunities for them, we need to understand what students see as valuable about education, the opportunities that they see as available to them in the contexts where schooling practices occur, and how they respond to these contexts.

\section{Bourdieu's forms of capital}

The appeal of the capability approach is the multidisciplinary character of its approach which keeps in mind all the aspects influencing the lives of people involved, analysing the changes that education would bring about in their capability sets. The challenge if the capability approach is that it is difficult to apply in practice, in part because of the multidisciplinarity, and in part because of the conceptual tension between valuing, reasoning about a person's values, and assessing their set of opportunities. ${ }^{1}$ In this paper, Bourdieu's (2006) forms of capital are used as conceptual tools to analyse the contexts in which a person can (or cannot) convert material resources to funtionings. First, Bourdieu's concepts of capitals are described and how they are used in integrating with Sen's capability approach. The following section will illuminate the workings of capitals and capabilities in specific contexts of Australia's 2015 PISA results.

Bourdieu (2006) identifies four forms of capital: economic (money and wealth assets), cultural, social, and symbolic. Bourdieu takes the idea of capital in the economic sense and employs it in a wider system of exchanges whereby assets of different kinds are transformed and exchanged within complex networks within social fields (Moore, 2008) - all forms of capital have currency in terms of economic value and people seek to gain advantage in the social fields based on their ownership of capital in those fields. Cultural capital exists as objectified through objects like possession of prestigious artwork; or embodied within the corporality of a person for example family upbringing; or institutionalised in the form of formal education (Bourdieu, 2006b: 106). Symbolic capital refers to goods or material that present themselves as worthy of being sought after in a particular social formation; and individual "practices" orient towards maximising their material or symbolic benefits as they attempt to derive advantages in social

\footnotetext{
${ }^{1}$ For a more detailed about conceptual tensions in the capability approach, see Pham, L (2016)
} 
situation (Bourdieu, 1977: 187). For Bourdieu, symbolic capital includes cultural capital and other forms of capital such as linguistic capital (for example English proficiency) or political capital (for example belonging to a political party). The practices by agents in deploying these forms of capital, which result in enhancing their power positions in the field, legitimate the symbolic capital itself (Pham \& Tran, 2015).

Social capital is defined by Bourdieu (2006b: 110) as an "aggregate of actual and potential resources linked to membership of a network of mutual recognition and acquaintance". As with cultural capital, social capital is linked to economic capital and relies on mutual acknowledgement of members in the group in an unconscious way to constitute its organised practices, which then exerts a multiplier effect on the social capital that the person owns (Bourdieu, 2006b: 110). Thus, social networks are results of members' investment strategies, individual and collective, that aim to establish and reproduce these relationships that they can then take advantage of (Bourdieu, 2006b).

According to Bourdieu (1977), people's ownership of various forms of capital denotes their position within the social hierarchies of their groups. In the educational context, the value of these forms of capital and associated advantages are enactment of the rules, codes that are shared by members within the social group (Moore, 2008: 105), which in turn, constitute their dispositions towards academic achievement. Nash (2002a) refers to this disposition as "educated habitus" - the learned set of preferences or dispositions by which a person orients to the social world. It is a system of durable, transposable, cognitive 'schemata or structures of perception, conception and action' (Bourdieu, 2002: 27). Habitus is rooted in family upbringing and conditioned by one's position in the social structure, which shape individual agency and perceived opportunity.

People deploy their owned capitals based on their habitus in the social fields that present the logic of people's practices (Bourdieu, 1977). Individuals' positions within a particular field are derived from the interrelation of their habitus and the capital they can mobilise in that field, which influence their decisions and behaviours in that field. Schools are fields in which students and educators occupy power positions based on their ownership of cultural capital, social capital and economic capital (Edgerton and Roberts, 2014). Seen from Bourdieu's perspective, unequal values and attitudes about education and differences in cultural resources valued in the education system means that students of different social origin are not equally positioned to benefit from equal access to education. Schools act as a social filter of privilege and exclusion in the sense that they select and socialise students on the basis of implicit social and cultural resources, or capital (Bourdieu, 2002). 


\section{Combining Bourdieu's capital and Sen's capabilities}

Bourdieu's capital and Sen's capability are both underscored by agency and freedom, which provide a fruitful lens to understand students' participation in schools and their outcomes. In this paper, Bourdieu's forms of capital are used as conceptual tools to understand the contexts in which a person can perceive available opportunities and mobilise their resources to convert them to doings and beings (functionings) he/she values (Sen, 1999). For example, how might a person's personal biographies such as family upbringing that act as cultural capital be mobilised in schools that connect them with cultural norms and expectations of the schools? How might their relations with teachers and principals cultivate the necessary social capital to enable them to interact with each other to gain advantage in classroom practices? How might their parents' past education act as symbolic capital that permits their voice within the schooling policies and committees? How might their socioeconomic background provide them with the material resources that allow them to gain access to and participate in the learnings offered?

Even though Sen recognises that there are personal, social and environmental factors that convert material resources to capabilities, he does not specify the conditions and contexts in which these factors are derived. Bourdieu's concept of capital can be useful to understand Sen's conversion factors in two interdependent ways. First, a person's owned material resources - economic capital can act as a means to achieve functionings (Sen 1999), According to Bourdieu (2006), other forms of capitals are translatable to economic capital so the former can also be used as a means to achieve functionings. Second, capital (cultural, social and symbolic) may convert material resources to capabilities if they provide the person with the opportunity or freedom to achieve functionings; but they may also limit the conversion of material resources to capabilities if they do not provide the person with the opportunity or freedom to achieve functionings. It is worthwhile to understand the contexts in which a person's owned capitals can enable resources to be converted to capabilities and the contexts in which they cannot. It must be noted that both Sen and Bourdieu emphasise that the contexts in which people live shape their values and goals for education. An analysis of contexts, thus, can provide insights into how people perceive opportunities and go about participating in schooling the way they do.

Analysing contexts can allow us to scrutinise the processes in which these students participate in schooling practices and the kind of choices of curriculum, learning and teaching practices they are inclined to value and take up. On the other hand, we can examine whether the types of capitals that students own predispose them to certain ways of learning that present them with different and unequal abilities to convert their resources to capabilities.

In integrating capital and capabilities in these ways, the analysis of education inequality goes beyond the issue of resources to understand what students perceive as opportunities that they can reasonably grasp with provided resources. This is important because even if resources are provided to all, not everyone will perceive opportunities to take those resources equally 
because their stock of capital may constitute certain dispositions to provided resources, or that their prior experiences of taking these resources may foster certain expectation about what they can do with such resources, or that their surrounding networks such as family, peers, teachers or principals may promote certain goals that may not align with their own educational goals - all of which can construct educational disadvantage. The proposed Sen-Bourdieu framework extends the focus of inequality from resources distribution to examine relational aspects of students in the school environment (student-teacher relationship, student-school relationship, teacher-school relationship, or teacher-policy makers relationships); and structural aspects of the schools (school systems and school structures). The next sections will illuminate how the Sen-Bourdieu framework can be applied to understand some of the PISA 2015 results in the Australian context that were surveyed in the OECD's PISA context assessment framework.

\section{Australia PISA 2015 - socioeconomic status and educational performance}

At the individual student level, PISA 2015 indicated that students from lower socioeconomic backgrounds ${ }^{2}$ performed lower than those from higher socioeconomic backgrounds (OECD 2016, Thomson et al. 2017). In fact, the difference between the highest percentile and lowest percentile of socioeconomic status was equivalent to around three years of schooling or one full proficiency level for Australia. In addition, the effect of socioeconomic background on performance in scientific literacy was higher in Australia compared to other countries across the OECD (OECD, 2017).

At the school level, regardless of their own socioeconomic background, Australian students enrolled in a school with a high average socioeconomic background tended to perform at a higher level than students enrolled in a school with a low average socioeconomic background (OECD 2016a). The amount of variance in performance between Australian schools attributable to socioeconomic status was lower than the OECD average; however, the amount of variance within Australian schools was greater than the OECD average (OECD, 2016a). These differences between schools and within schools means the school that an Australian student attend matters in terms of educational outcomes. It should be noted that Australia's fairness ${ }^{3}$ indicator was lower than the OECD average, and lower than other countries that outperformed

\footnotetext{
2 The OECD's PISA measures a student's socioeconomic background by the index of economic, social and cultural status (ESCS), which is based on the highest level of the occupation of the students' parents or guardians, the highest level of parents' education, and an index of home possessions that include educational resources, cultural possessions and other items in the home. The index was built to allow international comparisons and reflects many important differences across students and schools (OECD 2016c).

${ }^{3}$ OECD measured fairness as variation in performance between schools that is attributable to students and schools' socioeconomic status (OECD 2016)
} 
it in science literacy performance except for New Zealand, Singapore and Chinese Taipei (OECD, 2017) ${ }^{4}$

PISA socioeconomic status refers to a person's economic capital - Bourdieu's notion of economic capital is wealth and economic assets - distributing them into socioeconomic hierarchies (or socioeconomic percentile in PISA's terms). As noted earlier, PISA 2015 indicated that economic capital is a factor in explaining tests scores across all literacy domains, at the student level and at the school level. For example, in Australia, independent schools had a proportionally greater number of high socioeconomic background students than Catholic schools that in turn had a far greater proportion than government schools. Independent schools reported higher than average scores across all domains; although after adjusting for socioeconomic backgrounds, independent schools reported higher test scores than Catholic schools, suggesting that there are factors affecting performance other than socioeconomic backgrounds (OECD, 2016). Government schools reported on average lower performance scores across all domains tested. PISA 2015 also shows that average performance differences between school sectors in Australia generally disappeared once student and average schoollevel socioeconomic background were accounted for (Thomson et al. 2017).

\section{PISA context assessment framework}

The OECD also measures contexts and calculate statistical correlation between these contextual measures and PISA test scores (OECD, 2017). For instance, PISA 2015 found that at the classroom level, Australian students whose teachers adapt their instruction to their needs, knowledge and level of understanding performed higher than those who do not. Yet, those that were in socioeconomically advantaged schools tend to have the former, while those in lower socioeconomic schools do not (OECD, 2016b). Another factor that PISA 2015 claimed affects test scores was skipping school (OECD 2016b). In most school systems that participated in PISA 2015 , students in socioeconomically disadvantaged schools were more likely to have skipped a day of school than students in advantaged schools. In Australia, student truancy, students' use of alcohol or illegal drugs, or students intimidating or bullying other students hindered student learning. These phenomena occurred more in jurisdictions with higher proportions of low socioeconomic students and schools (Thomson et al. 2017).

At the school level in Australia, Thomson et al. (2017) found that the type of school (independent, government, Catholic), its location, sources of funding, wealth, educational values, and parents' involvement impact students' outcomes. Other non-economic factors that associate with performance include time spent in regular science lessons, after school. Again, these factors tend to occur more in schools with higher socioeconomic status.

\footnotetext{
${ }^{4}$ Schools in Singapore and Taipei enrol students based on academic abilities which may explain the low fairness indicator in these countries (OECD 2017).
} 
These results indicate that there are other factors that contribute to achievement in schools besides economic capital, but they are also influenced by economic capital at the educational system level, school level, and at the individual student level. In other words, distribution of economic, social and cultural diversity within and between Australian schools influences the fairness of test outcomes and academic inclusion of students ${ }^{5}$ (OECD, 2016).

PISA 2015 implications for Australia's policy landscape are undoubtedly about levelling educational differences that relate to differential economic capital ownership. These PISA results also suggest the applicability of the interdependent nature of Bourdieu's forms of capitals in enabling material resources such as economic capital to be converted to educational capabilities (see earlier discussion). The OECD's PISA 2015 context assessment framework (Figure 1) that underpinned the context questionnaires to parents, students, teachers and principals ${ }^{6}$ shows the contextual indicators that the OECD considers impacting PISA test scores. This framework clearly suggests that the OECD is interested in measuring students' engagement at school, dispositions towards school and their self-beliefs, and in gathering information about students' backgrounds and the learning environment at school. However, these snapshots of context measures fall short of explaining how and why they are contributing factors to students' access to school resources and practices which the OECD considers inclusion, and their engagement in the process of schooling to produce differential performance which the OECD considers fairness. Thus, the OECD's (2016b) focus on resources in schools to improve educational disadvantage seems odd and without logic. The focus on existing options of curriculum and conditional on whether teachers provide support in these selections and the subject teachings seems detached from consideration of valuable real choices for students that may allow them some self-determination and freedom to participate effectively in schools. Even though the OECD aims to address broader policy issues associated with PISA test scores through measures of contexts and non-cognitive outcomes (for example students' motivation, interest, beliefs, career aspirations, general behaviour and attitudes), it is not clear what derives the statistically established link of economic capital and educational disadvantage; the latter is useful for policy implications.

\footnotetext{
5 The OECD has two measures of inclusion: 1) access to schooling; 2) proportion of students at or above baseline level of test scores

${ }^{6}$ Student Questionnaire, the School Questionnaire (completed by school principals), the optional Parent Questionnaire (completed by parents of students who sat the PISA test), the optional Educational Career Questionnaire (completed by students, concerning their educational and career aspirations), the optional ICT Familiarity Questionnaire (completed by students, concerning their attitudes towards and experience with computers) and the optional Teacher Questionnaire (completed by teachers, and introduced in PISA 2015)
} 
Figure 1. PISA 2015 context assessment framework (adapted from OECD 2016c)

\begin{tabular}{|c|c|c|c|c|}
\hline Student & \multicolumn{3}{|c|}{ Processes } & \multirow{2}{*}{$\begin{array}{l}\text { Students' non- } \\
\text { cognitive } \\
\text { outcomes }\end{array}$} \\
\hline Family & Actors & Core processes & $\begin{array}{l}\text { Resources } \\
\text { allocation }\end{array}$ & \\
\hline & $\begin{array}{l}\text { 5.Teacher } \\
\text { qualification and } \\
\text { professional } \\
\text { knowledge } \\
\quad \text { Classroom }\end{array}$ & level: Teaching & $\begin{array}{l}\text { 7.Learning time } \\
\text { and curriculum }\end{array}$ & $\begin{array}{l}\text { 16.Motivation, } \\
\text { interest, beliefs }\end{array}$ \\
\hline $\begin{array}{l}\text { 1.Student SES } \\
\text { and family }\end{array}$ & & $\begin{array}{l}\text { 10.Learning } \\
\text { environment }\end{array}$ & & \\
\hline $\begin{array}{l}\text { 2.Ethnicity and } \\
\text { immigration } \\
\text { 3. Out-of-school } \\
\text { experience }\end{array}$ & $\begin{array}{l}\text { 8.Parental } \\
\text { involvement }\end{array}$ & $\begin{array}{l}11 . \text { School } \\
\text { climate: } \\
\text { interpersonal } \\
\text { relations, trust, } \\
\text { expectations }\end{array}$ & 12.Resources & $\begin{array}{l}\text { 17.Career } \\
\text { aspirations } \\
\text { 18.General } \\
\text { attitudes and } \\
\text { behaviour }\end{array}$ \\
\hline $\begin{array}{l}\text { 4. Education } \\
\text { pathway in } \\
\text { early childhood }\end{array}$ & $\begin{array}{l}\text { 9.Leadership } \\
\text { and school } \\
\text { management }\end{array}$ & & & $\begin{array}{l}\text { 19.Dispositions } \\
\text { for collaborative } \\
\text { problem solving }\end{array}$ \\
\hline \multicolumn{5}{|c|}{ School level: School policies } \\
\hline & $\begin{array}{l}\text { 13.Locus of } \\
\text { decision making } \\
\text { within school } \\
\text { system } \\
\quad \text { Sys }\end{array}$ & $\begin{array}{l}\text { 14.Assessment } \\
\text { evaluation and } \\
\text { accountability }\end{array}$ & $\begin{array}{l}\text { 15. Allocation, } \\
\text { selection and } \\
\text { choice }\end{array}$ & \\
\hline
\end{tabular}

The PISA background questionnaires to parents, teachers, students, principals survey each of the 19 items in Fig 1. Items 1 to 4 (first column) measure background characteristics related to their family and the education they received. Items 16 to 19 (last column) measure the non-cognitive outcomes of education and aspects of students' lives, such as their attitudes towards learning, their habits and life inside school, and their interest, motivation and engagement. Items 5 to 15 (middle columns) measure the education processes and resources at three levels: school system, school and classroom. These processes include educational processes of teaching and learning, human and material resources and actors responsible for managing resources and processes.

The problem with PISA 2015 context measures as meaningful ways to explain education performance is multi-fold. From a methodological perspective, cross-sectional presentation of 
test scores cannot capture students' developmental processes underlying test performance. Although PISA 2015 acknowledges that the developmental processes that give rise to noncognitive aspects such as attitudes, teaching and learning engagement are important in the opportunities and processes of education, the focus of cross-sectional survey is not informative for understanding how these can be changed.

From a conceptual perspective, the OECD considers processes within the school system and at classroom levels as measures in themselves, rather than look at how background characteristics of students may impact the way they participate in the processes, or that the processes within schools and classrooms may favour certain groups over others. This, too, is because contexts are measured at a point in time rather than evaluating contexts as processes that students take up and progress in schools.

The OECD also acknowledges that educational efficiency can be achieved if we understand the relation between outcomes and resources (OECD, 2016a, 2016b); but the simplistic ways that resources are presented at the school and classroom level, do not help to understand how those resources allocation can translate students' personal attributes to forms of capital that they can use and that are favourable to achieve cognitive (test scores) and noncognitive outcomes (attributes, beliefs, motivations).

Lastly, the OECD considers the importance of freedom and autonomy mainly at the school governance level, primarily the autonomy of principals, teachers, school boards in relation to curriculum, enrolment, assessment and resources allocation. It does not look at how these policies and practices provide students with real choices that enable them to access and participate in the school curriculum, enrolment, assessment and resources in ways that they can convert these resources within those processes to functionings that they value.

\section{Applying the Sen-Bourdieu framework}

The Sen-Bourdieu framework can be applied to address some of the shortfalls of PISA 2015 context measures to understand the generative mechanisms of educational inequality as disclosed via PISA tests performance. For example, we can analyse the background characteristics of students (items 1 to 4 ) in terms of students' stock of capital, and how those forms of capital construct their perceived opportunities, their decision to take up opportunities (or choices) and engagement in schooling processes and resources offered at schools (items 5 to 15). We can interrogate how these forms of capital shape students' aspirations, motivations (items 16 to 19). We can examine students' participation in schooling processes in terms of deploying capitals and associated consequences in terms of cognitive and non-cognitive outcomes (items 10 to 11). As the PISA contexts assessment is wide ranging, analyses of empirical data other than PISA results are required to explicate the Sen-Bourdieu framework 
and its multidisciplinarity. Such analyses need to be multidimensional, multilevel quantitative studies and supplemented by multidimensional qualitative studies to provide substantive insights about the forms of capital that enable or hinder students in accessing and participating in school practices and institutional structures, and whether those ongoing practices and structures privilege certain background characteristics while marginalise others. The remaining parts of this section illustrate some ways that the Sen-Bourdieu concepts can be used to guide the analysis of the schooling contexts (structural, relational, representational) at the three levels that the PISA context assessment framework operates (student, school and school system), As the PISA contexts assessments framework covers a wide range of contexts, the discussion aims to be illustrative of the application of the Sen-Bourdieu concepts rather than a comprehensive analysis.

\section{Student level}

Students' economic capital, as found by PISA 2015, contributes to positive academic performance in the following ways. More educated parents are able to provide a richer set of learning opportunities at home, more access to written materials for reading, travel, and other resources that engage their child's curiosity (Lareau and Weininger, 2003; Wilmms, 2006). They have high expectations for their children's academic performance and interest in their school work, which in turn, are converted to parental participation in school and out of school tuition (Avvisati, 2014; OECD 2011). Barone (2006) and Tramonte and Willms (2010) found that communications, discussions and cultural experiences within the family had a large effect on reading-related achievement than did the reading materials in static forms. In other words, economic capital provides material resources that give students the means to achieve educational functionings. Associated with economic capital is embodied cultural capital of family resources that may align parents' interest and expectations with those of the schools, which in turn lead to parental involvement with the schools (item 8) and position students with advantage (Catsambis, 2002; Desforges and Abouchaar, 2003; Lareau, 2002, 2011). Interestingly, PISA 2015 found that across education systems that distributed the parents' questionnaire, parents of children who attend socioeconomically disadvantaged schools reported having participated in more school-related activities than parents of children who attend advantaged schools (OECD, 2016b), and that the performance of students tend to be lower for those that attend schools with higher level of parental contact with schools. These indicators, which captured only parents' contact with the schools, suggest that there are other factors that impact the effects of cultural capital in the field which need further investigation.

Bourdieu's linguistic capital is represented in the ethnic and immigrant background of students (item 2) which PISA 2015 views to be relevant in shaping experiences of students. On the one hand, this form of capital may foster the development of language awareness and 
facilitate the learning of additional foreign languages. On the other, lower competency in English, which is the language of instruction in Australia can negatively affect learning in other subjects and in the long run be disadvantageous for students' educational pathways. Linguistic diversity is a resource that students own, but whether they can mobilise it in schools depend on the linguistic capital of teachers, other students, and schooling curriculum and teaching and learning practices - the structural contexts. If students are not able to share their linguistic capital, or their linguistic capital is not appreciated, they can encounter barriers in the classroom, particularly if teachers do not have adaptive teaching skills required to deal with comprehension difficulties and likely cultural differences. In trying to mobilise their linguistic capital, students from ethnic backgrounds may have to adjust to unfamiliar cultural contexts at school (Bullock, 2018) and they may face discrimination (Perreault and Bourhis, 1999). In other words, the ability of students to deploy linguistic capital depend on whether their cultural diversity is recognised and appreciated by those around them.

Furthermore, PISA 2015 results indicate that educational performance of students from diverse backgrounds differ and is linked to economic capital. For example, PISA 2015 found that students from ethnic backgrounds on average performed worse than those with English as first language. However, students from ethnic background who are in top quartile of socioeconomic status performed better than their counterparts whose first language is English. They also have higher career aspirations. This finding suggests that linguistic capital may translate to embodied cultural capital that can be used effectively by some students notably those with high economic capital. PISA 2015 found that educational aspirations vary between different ethnic groups regarding their quality and stability (Kao and Tienda, 1998; Mau et al., 2000) and can be a significant predictor of the students' future educational attainment (Thiessen, 2007). In this regard, career aspirations (item 6) can be viewed as a process rather than a fixed point, because students are predisposed to certain expectations associated with family upbringing and prior experiences that are related to economic capital (Appadurai, 2004). This does not mean aspirations are symptomatic of students' backgrounds, rather they are mutable as students try to mobilise their cultural capital in the social field (Pham, 2018). To understand how linguistic capital may enable or limit students' opportunities and participation in schooling practices, it is important to make visible overlapping forces and processes at schools and how schools or teachers reward or penalise students in their deployment of linguistic capital in various situations.

\section{School level}

PISA 2015 measures teaching practices in terms of teacher support, cognitive challenge that teachers provide to students, and disciplinary climate (items 6, 10 and 11). These indicators can be understood through Bourdieu's social capital that constitute teacher-student relations. 
According to Bourdieu (2006), people mobilise their social networks to accumulate networks as part of strategic investment to accumulate economic capital. Teachers' education and training, expertise and attitudes to students - which are derived from their habitus - inform the quality of instruction, structure of their teaching, the support and challenge they are willing to impart to students. These, in turn shape the opportunities that they can provide students and the opportunities that students perceive as available to them, that is their real opportunities. For example, implemented curriculum, assigned tasks and activities, instructional time, grouping, assessment and feedback are products of teachers' education and training, as much as the school polices that inform about allocated learning time, extracurricular activities, evaluation and assessment policies (OECD, 2016b); both comprising the structural contexts in which students engage with teachers and the school.

Another example is the role of inquiry-based teaching practices, which PISA views as positive effect on student learning, particularly students' engagement in the cognitive dimensions of inquiry and teacher-led inquiry activities (Furtak et al., 2012). However, these practices should be examined in terms of students' disposition toward such learning practices rather than assuming all students would perceive opportunities for this type of learning in similar positive ways. As Edgerton and Roberts (2014) pointed out, some students enter school with dispositions that align well with the school expectations and teaching practices. They have the cultural capital that they can mobilise in ways that are congruent to classroom practices which in turn will enable them to convert their resources (for example prior knowledge, learning style) to academic achievement. For instance, middle class families tend to engage more in reasoning, negotiation and talking as a form of discipline (Lareau, 2002, 2011). Students with such family upbringing are thus predisposed to teaching and learning practices that orient toward talking, discussing, and problem solving that are captured in item 19. So, it is important to understand which forms of capital students have, and whether their ownership or lack of capital, position them differentially to schooling practices offered.

While PISA refers to teacher-student behaviours as the disciplinary climate (OECD, 2016b), the context framework speaks loudly of the cultural contexts and teachers and students' values of education. PISA contexts questionnaire results show a positive association between teacher support and education performance for Australian schools (OECD, 2016b), which PISA 2015 suggests is attributable to interactions between students and teachers within a disciplinary climate. The question is how does this form of social capital contribute to a disciplinary climate that provide the means or opportunity for students to achieve educational performance? A possible answer to this question is the intersection of cultural capital and social capital at the school level. For example, if the school recognises students' linguistic and cultural diversity and permits their representation through parental involvement, these contexts can 
promote collaboration between students and teachers, school leaders and teachers and parents and school (item 8, 9, 11, 19).

In addition, cultural capital shapes achievement orientation, shared norms, leadership, teacher morale and co-operation, professional development, high expectations and support for academic learning (Edgerton and Roberts, 2014). Parents who know what schools expect by being familiar with the school programs and teaching and learning practices share with the schools a general appreciation of education and related values (Lareau and Cox, 2011). While cultural capital can be enhanced by accumulating social capital and vice versa, it must be noted that lack of cultural capital can create barriers if accompanied by lack of social capital. This may explain the reason behind PISA's 2015 claim that Australian schools with low socioeconomic status did not have teaching and learning practices or disciplinary climate that are conducive to educational performance despite the lack of statistically significant relationship between parent involvement and educational performance.

Cultural and social capital can be used to examine the extent to which students find a fit or match with their schools, whether they are recognised, valued and embraced by their schools. Such alignment is contingent on who the students are, their habitus, experiences encountered outside and inside schools (Bourdieu and Wacquant 1992, Nunez 2014). The transferability of cultural and social capital in shaping opportunities and enabling processes of students' agency suggests the need to understand how teachers adjust to students' values and needs, students' connection with other students and being part of the school community. The school culture influences students' dispositions to the values that are expected of them. Those that find their school climate to be an extension of home life experience a match between their norms and school norms - a habitus that is congruent with school standards and expectations (Edgerton and Roberts, 2014). For others, the school processes may represent a mismatch. The match or mismatch of students' habitus with the school can encourage or hinder their ability to use their owned capitals to convert material resources to achieve educational functionings that they value. In addition to knowing the forms of capital that can be used to convert resources to educational capabilities, it is useful to understand the cultural and social capital and habitus mismatch to explain the achievement gap between students within and between schools that PISA pointed to, particularly students with Indigenous and ethnic backgrounds or those in rural and remote locations.

\section{System level}

PISA 2015 examines the governance process at the school system level by measuring the locus of decision making by the school board, staff and school leaders about admission, curriculum, allocation of resources and personnel (item 17). Leadership and school management (item 15) is emphasised in PISA 2015 with the assumptions that these governance indicators shape 
teachers' professional development, define the school's education goals, and ensure that instructional practice is directed towards achieving these goals. While PISA 2015 acknowledges that research has shown that teachers' perspective on leadership can differ from the positions held by school administrators, it is silent on the situational contexts in which these perspectives can differ and consequences on students' learning opportunities. Two aspects about school leadership that could help to better understand PISA's findings in relation to educational inequality. First, understanding how leadership operates at the school level and classroom level across three sectors can help to identify the structural contexts in which students engage with the school. For example, analysis of students' choice and choice options in curriculum and enrolment in schools can shed light on their displacement or excessive mobility associated with poor school performance, particularly for students with special needs. Bourdieu's symbolic capital can be useful to understand the perception of private schools in Australia as better schools, safer schools (PISA 2015), which results in parents sending their students to private schools because of the symbolic capital attached to those schools. Kenway (2013) argued that selective school and private school system in Australia create a "ghetto" movement where socioeconomically advantaged students flock to the private sector and leaving the rest in the public schools which are least able to provide them with teaching and learning that meet their educational needs and further disadvantage them.

Second, even though PISA 2015 focuses on teachers' background and initial education and acknowledges the need to understanding the multiple pathways leading to the teaching profession, professional development and its impact on quality instruction and teacher retention (OECD, 2016b, 2010), it does not explain how these forms of institutionalised cultural capital inform teaching practices and student achievement. The overall status of teachers is important because it affects the perceived attractiveness of the profession - a symbolic capital that can explain the type of people that choose teaching as a career pathway. In addition to the generally less specialised field of knowledge and postgraduate qualification that Australian teachers have compared with other countries such as Singapore, the United States, Finland (PISA 2015), teachers in Australia generally do not have higher status in the field or broadly in society, compared to Asian countries where education is much more valued, and teachers are more respected. These aspects inevitable shape the social relations and interactions between teachers and students and as discussed in the previous part, affect how students engage with schooling and classroom practices.

\section{Conclusions and implications for social justice policies in education}

This paper offers a framework that combine Sen's concept of capability and Bourdieu's forms of capital to highlight structural, representational and relational aspects that could mediate 
students' access to and participation in schools. The paper has broadly illustrated how Bourdieu's forms of capital can be used to understand the PISA contexts measures that relate to PISA 2015 performance for Australia. It is the relationships between forms of capital (cultural, social, linguistic, symbolic) and their transferability to economic capital that influence educational performance. Students' stock of capital influences their attitudes toward schools, participation in schools, behaviours in and out of schools. These forms of capital are representative of their habitus of family background and past experiences. From a capability perspective, capital construct opportunities that students perceive available to them and the means in which they make use of material resources. The extent to which these forms of capital help or constrain students in converting resources to educational capabilities depend on the school structures and schooling practices. For instance, schools that do not recognise cultural diversity may embed (whether this is intentionally or not) curricular materials and pedagogical arrangements in schooling practices that place individuals from ethnic background in unequal positions in their educational experiences (Bourdieu, 1977).

The Sen-Bourdieu framework has significant policy implications for improving equity in education. First, it offers expanded informational bases beyond socioeconomic categories to better understand the forms of capitals that students own as conditions and conditionings of their desired doings and beings in different circumstances. In doing so, it considers the intrinsic value of students' lives and backgrounds, and plurality of their educational values and aspirations. These aspects of capabilities can then be incorporated in the design of policies and processes in schools and classroom practices.

Second, intersecting capital and capabilities attend to possibilities of improving equity beyond provision of economic capital (not to say that economic capital is not important), to providing students with the forms of capital that enable them to make choices that they can realistically access, and that they can deploy resources in ways that they value. It may also give us insights into ways to enhance students' ownership of the types of capital that can improve their processes in agentic engagement with schools, and networks in schools, employment or civic activities. For example, if connections between peers are the social capital necessary to enable students from marginalised group to interact with the class, the schools may consider a buddy system that pair students from different social groups. If relationships with teachers provide students with the social capital necessary for them to engage with teaching and classroom activities, then additional student-teacher time should be afforded to these students either in class or out of class. This would require concerted effort by the school as well as additional resources.

While economic capital is important, the extent to which economic capital work effectively to produce positive educational outcomes depend on the mobilisation of other forms of capital, and the contexts in which they are mobilised. As this paper has illustrated, inequality 
can arise from aspects of school structures, relationships between schools and students, teachers and students, and representation of students and their families in the school community. Disabling factors to educational achievements can also be embedded in curricular materials, pedagogical arrangements and learning experiences of students of different backgrounds, which tend to reinforce exclusion and inequality. If we are aware of the effects of these aspects in schooling practices, we can design capability-informed policies to address mechanisms of inequality.

Third, thinking about social justice through the lens of capabilities puts policy attention to agency of students. This paper suggests that it is important to pay attention to the processes that students take up learning in schools, and how such experiences may shape their perception and pursuit of future opportunities. Sen's vision of agency in the capability approach emphasises on not what people be and do, but that they be and do the things they choose to be and do as they see valuable. The policy implications for improving equity are to improve access to school by redistribution of resources, which is already at the centre of Australia's policy debate (exemplified by the Gonski needs-based funding model). In addition, this paper suggests that it is important to provide curriculum and learning and teaching practices that are responsive and inclusive of all students from diverse backgrounds and needs to provide them the opportunity (or freedom) to achieve learning outcomes with sense of self-determination and agency. In this regard, the paper provides the ground for examining social justice in ethical ways by placing individual participation in their society and their normative wellbeing at the forefront rather than looking at resources with the assumption that they will be accessed by all in similar ways with similar outcomes.

This paper has shown that understanding the dominant forms of capital and their interdependent links in enabling or disabling students' capabilities is worthwhile to contribute to a fruitful and human centred discussion about social justice policies in education. Much more work is required to achieve detailed and multilevel quantitative studies about accumulation of capital and capabilities to understand dynamic effects of schooling practices and students' dispositions to those practices within and across student groups. These studies must be supplemented with qualitative analysis of the social relations and structures in schools to identify and explain generative mechanisms of educational inequality.

\section{Funding}

The author(s) received no financial support for the research, authorship, and/or publication of this article. 


\section{References}

Agosto, V. and Roland, E. (2018) Intersectionality and Educational Leadership: A Critical Review. Review of Research in Education 42 (1): 255-285.

Appadurai, A. (2004). The Capacity to Aspire: Culture and the Terms of Recognition. In: Rao, V and Walton M (eds) Culture and Public Action. Stanford: Stanford University Press, pp. 59-84.

Arendt, H. (1958) The Human Condition: A Study of the Central Dilemmas Facing Modern Man. Chicago: University of Chicago Press, pp 6-7.

Australian Treasury (2004). Report, Economic Roundup, Winter, Australia.

Avvisati, F., Gurgand, M., Guyon, N. and Maurin, E. (2014) Getting parents involved: A field experiment in deprived schools. The Review of Economic Studies 81 (1): 57-83.

Barone C (2006) Cultural capital, ambition and the explanation of inequalities in learning outcomes: A comparative analysis. Sociology 40 (6): 1039-1058.

Benmayor, R. (2002). Narrating cultural citizenship: Oral histories of first-generation college students of Mexican origin. Social Justice 4 (90): 96-121

Blanchard, M.R., Sherry A. Southerland, S.A, Osborne, J. W., Sampson, V.D., Annetta, L. A., and Granger, E.M. (2010) Is inquiry possible in light of accountability? A quantitative comparison of the relative effectiveness of guided inquiry and verification laboratory instruction. Science Education 94 (4): 577-616.

Bourdieu, P. (1977) Outline of a Theory of Practice. Cambridge: Cambridge University Press.

Bourdieu P. (1990) The Logic of Practice. Cambridge: Polity Press.

Bourdieu P. (2002) Habitus. In: Hillier J and Rooksby E (eds) Habitus: A Sense of Place. Burlington, VT: Ashgate, pp. 27-34

Bourdieu P. (2006a) Cultural reproduction and social reproduction. In: Grusky DB and Szelényi S (eds) Inequality: Classic Readings in Race, Class, and Gender. Boulder, CO: Westview Press, pp. 257-271

Bourdieu, P. (2006b) The Forms of Capital. In: Lauder H, Brown P, Dillabough, J-A and Halsey A.H (eds). Education, Globalisation \& Social Change. Oxford: Oxford University Press, pp. 105118

Bourdieu, P. and Passeron, J. (1977) Reproduction in Education, Society and Culture. Sage: London.

Bourdieu P and Wacquant L.J.D. (1992) An Invitation to Reflexive Sociology. Chicago, IL: University of Chicago Press.

Bullock, E.C. (2018) Intersectional Analysis in Critical Mathematics Education Research: A Response to Figure Hiding. Review of Research in Education 42 (1): 122-145.

Catsambis, S. (2002) Expanding knowledge of parental involvement in children's secondary education: Connections with high seniors' academic success. Social Psychology of Education 5 (2): 149-177.

Collins, P. H. (2007) Pushing the boundaries or business as usual? Race, class, and gender studies in sociological inquiry. In: Calhoun C. (ed.), Sociology in America: A history. Chicago, IL: University of Chicago Press, pp. 572-604.

Desforges, C. and A. Abouchaar (2003) The Impact of Parental Involvement, Parental Support and Family Education on Pupil Achievements and Adjustment: A Literature Review. Report, Department for Education and Skills, Nottingham.

Domina, T. (2005) Leveling the home advantage: Assessing the effectiveness of parent involvement in elementary school. Sociology of Education 78 (3): 233-249.

Edgerton, J. and Roberts, L. (2014) Cultural capital or habitus? Bourdieu and beyond in the explanation of enduring educational inequality. Theory and Research in Education 201412 (2): 193-220. 
Gorecki, S., and Kelly, J. (2012) Treasury's Wellbeing Framework. Report, Economic Round 3, Australia.

Furtak, E.M., Seidel, T. Iverson, H. and Briggs, D.C. (2012) Experimental and quasi-experimental studies of inquiry-based science teaching: a meta-analysis. Review of Educational Research 82 (3): 300-329.

Hart, C. S. (2013) Aspirations, Education and Social Justice: Applying Sen and Bourdieu. London: Bloomsbury.

Henry, K. (2009) How Much Inequity Should We Allow? Address to the Australian Council of Social Service National Conference, Sydney, April 2-3.

Hinz, S. E. (2016) Upwardly mobile: Attitudes toward the class transition among firstgeneration college students. Journal of College Student Development 57: 285-299.

Kao, G. and Tienda, M. (1998) Educational Aspirations of Minority Youth. American Journal of Education 106 (3): 349-384.

Keddie, A. (2012) Schooling and social justice through the lens of Nanny Fraser. Critical Studies in Education, 53(3) 263-279.

Kenway, J. (2013) Challenging inequality in Australian schools: Gonski and beyond. Discourse: Studies in the Cultural Politics of Education 34 (2): 286-308.

Lareau A. and Cox A. (2011) Social class and the transition to adulthood: Differences in parents' interactions with institutions. In: Carlsson M and England P (eds) Social Class and Changing Families in an Unequal America. Stanford, CA: Stanford University Press, pp. 134-164

Lareau A. and Weininger, E.B. (2003) Cultural capital in educational research: A critical assessment. Theory and Society 32: 567-606.

Lareau A. and Weininger, E.B. (2008) Class and the transitions to adulthood. In: Lareau A. and Conley D. (eds) Social Class: How Does It Work? New York: Russell Sage. pp. 118-151.

Longwell-Grice, R., Longwell-Grice, H. (2008) Testing Tinto: How do retention theories work for first-generation, working-class students? Journal of College Student Retention 9: 407-420.

Martins, N. (2007) Ethics, Ontology and Capabilities. Review of Political Economy 19(1): 37-53

Mau, W-C, Heim, L. and Bikos, L. H. (2000) Educational and Vocational Aspirations of Minority and Female Students: A Longitudinal Study. Journal of Counselling and Development 78 (2): 186-194.

Moore, R. (2008) Capital. In: Grenfell M (ed). Pierre Bourdieu Key Concepts. Durham: Acumen, pp. 101-118.

Nash, R. (2002a) The educated habitus, progress at school, and real knowledge. Interchange 33(1): 27-48.

Nash R. (2002b) Numbers and narratives: Further reflections in the sociology of education. British Journal of the Sociology of Education 23(3): 397-412.

Núñez, A. M. (2014) Employing multilevel intersectionality in educational research Latino identities, contexts, and college access. Educational Researcher 43 (2): 85-92.

Nussbaum, M. (2006). Education and democratic citizenship: Capabilities and quality education. Journal of Human Development 7 (3): 385-395.

OECD (2011) Quality Time for Students: Learning In and Out of School. PISA, Paris: OECD Publishing.

OECD (2016a) PISA 2015 Results (Volume I): Excellence and Equity in Education. PISA, Paris: OECD Publishing.

OECD (2016b) PISA 2015 Results (Volume II): Policies and Practices for Successful Schools. PISA, Paris: OECD Publishing

OECD (2017) PISA 2015 Assessment and Analytical Framework: Science, Reading, Mathematic and Financial Literacy. PISA, Paris: OECD Publishing 
Perreault, S. and Bourhis, R. (1999) Ethnocentrism, Social Identification, and Discrimination Personality. Social Psychology and Discrimination 25 (1): 92-103.

Pham, L. (2015) Rethinking international education through the concept of Capabilities: a bridge to development in Asia's emergent knowledge societies. Confero: Critical Essays in Philosophy and Education 3(1): 1-36.

Pham (2016) Understanding the transformative potential of international education for Vietnamese overseas graduates and their communities. PhD Thesis, Macquarie University, Australia.

Pham, T. L and Tran, T (2015) Understanding the symbolic capital of intercultural interactions: A case study of international students in Australia. International Studies of Sociology in Education. 25(3): 204-224.

Pham, L. (2018) Aspirations of Vietnamese overseas-trained graduates in their homeland. In: Tran L and Marginson M (eds) Internationalisation of Vietnamese Higher Education. Melbourne: Springer.

Robeyns, I. (2003) Is Nancy Fraser's Critique of Theories of Distributive Justice Justified? Constellations 10(4): 538-553. Blackwell Publishing

Robeyns, I. (2008) Three models of education: Rights, Capabilities and Human Capital. Theory and Research in Education 4(1): 69-84.

Robeyns, I. (2011) The Capability Approach. Stanford Encyclopaedia of Philosophy. Summer of 2011 Edition. Available from http:

//plato.satnford.edu/archives/sum2011/entries/capability-approach (accessed 8 October 2013).

Sen, A. (1985a) Goals, Commitment and Identity. Journal of Law, Economics \& Organization 1(2): 206-224.

Sen, A. (1985b) Well-being, agency and freedom: the Dewey Lectures 1984. Journal of Philosophy 82: 169-221.

Sen, A. (1997a) Editorial: Human Capital and Human Capability. World Development 25 (2): 1959-1961.

Sen, A. (1997b) Human Capital and Human Capability. World Development 25(12): 1959-1961.

Sen, A. (1999) Development as Freedom. Oxford: Oxford University Press.

Sen, A. (2002) Rationality and freedom. Cambridge, MA: The Belknap Press of Harvard University Press.

Sen, A. (2009) The idea of justice. Cambridge, MA: The Belknap Press of Harvard University Press.

Smith, M. L and Seward, C. (2009) The Relational Ontology of Amartya Sen's Capability Approach: Incorporating Social and Individual Causes. Journal of Human and Development and Capabilities 10 (2): 213-235.

Thiessen, D. (2007) Curriculum and Social Change. Curriculum Enquiry 37 (4): 299-302.

Thomson, S., De Bortoli, L. and Underwood, C. (2017) PISA 2015: Reporting Australia's results. Available from https://research.acer.edu.au/ozpisa/22 (accessed 12 February 2018).

Tramonte, L. and Willms, J.D. (2010) Cultural capital and its effects on educational outcomes. Economics of Education Review 29: 200-213.

Vaughan, R. (2007) Measuring Capabilities: An Example from Girls' Schooling. In: Walker M and Unterhalter E (eds). Amartya Sen's Capability Approach and Social Justice in Education. New York: Palgrave Macmillan, pp. 109-130.

Walker, M. (2006) Towards a Capability-based Theory of Social Justice for Education Policymaking. Journal of Education Policy 21 (2): 163-185. 
Walker, M., and E. Unterhalter (2007) The Capability Approach: Its Potential for Work in Education. In: Walker M and Unterhalter E (eds) Amartya Sen's Capability Approach and Social Justice in Education. New York: Palgrave Macmillan, pp. 1-18.

Willms, J.D. (2006) Learning Divides: Ten Policy Questions about the Performance and Equity of Schools and Schooling Systems. Report, UNESCO Institute for Statistics, Montreal, Canada. 